\title{
Assessment of the antagonistic potential and ability of biofilm formation of Enterococcus spp. isolated from Serbian cheese
}

\author{
Mirjana Ž. Grujović ${ }^{*}$, Katarina G. Mladenović'1, Tanja D. Žugić-Petrović́, \\ and Ljiljana R. Čomić1
}

${ }^{\prime}$ Department of Biology and Ecology, Faculty of Science, University of Kragujevac, Kragujevac, Serbia

${ }^{2}$ College of Agriculture and Food Technology, Prokuplje, Serbia

GRUJOVIĆ, M. Ž., K. G. MLADENOVIĆ, T. D. ŽUGIĆ-PETROVIĆ, LJ. R. ČOMIĆ: Assessment of the antagonistic potential and ability of biofilm formation of Enterococcus spp. isolated from Serbian cheese. Vet. arhiv 89, 653-667, 2019.

\section{ABSTRACT}

In this paper, the presence, biochemical and physiological characteristics of the members of genus Enterococcus, isolated from traditionally made Serbian cheese, were investigated. The members were identified as: Enterococcus faecium (8 isolates), E. faecalis (14 isolates), E. hirae (4 isolates) and E. durans (4 isolates), using the biochemical tests and MALDI-TOF mass spectrometry. All the tested isolates showed good acidification ability in pure and enriched milk. The antagonism of enterococci on the growth of Escherichia coli ATCC 25922, Proteus mirabilis ATCC 12453, Klebsiella oxytoca KGPMF1, Klebsiella ornithinolytica KGPMF8 and Aeromonas hydrophila, as well as their ability to form biofilms, were examined. The tested isolates showed moderate inhibitory activity $(10-22 \mathrm{~mm})$ on the growth of the indicator strains. Among all the isolates, only E. hirae KGPMF9 and E. faecium KGPMF14 showed the ability of biofilm formation. The results provide a basis for further research into the possible practical application of the isolated enterococci.

Key words: antimicrobial potential; biofilm; Enterococcus faecium; Enterococcus faecalis; Enterococcus durans; traditionally made cheese

\section{Introduction}

The southeastern region of Serbia is a geographical area known for a traditional way of producing many dairy products. In this region, the people produce Sokobanja cheese, made from raw, unpasteurized cow's milk, without adding a bacterial starter culture (MURUZOVIĆ et al., 2018a, 2018b). The nutrition of dairy cows, the traditional cheese-making process and the natural bacteria responsible for the fermentation

\footnotetext{
${ }^{*}$ Corresponding author:

Grujović Mirjana; University of Kragujevac, Faculty of Science, Department of Biology and Ecology, Radoja Domanović 12, 34000 Kragujevac, Serbia, Phone: +381 34336 223; E-mail: mirkagrujovic@gmail.com
} 
process and ripening seem to have a significant role in the formation of the flavor and typical organoleptic properties of cheeses made from raw milk (TERZIĆ-VIDOJEVIĆ et al., 2009). This kind of product can be a main source of probiotic microorganisms (MOTAHARI et al., 2017).

Enterococci are expected to grow in cheese made from raw milk, either as natural or added microflora (cheese starter cultures, or as adventitious microflora, through environmental, post-pasteurisation contamination). Enterococci are an important part of the bacterial count in different types of traditional cheeses (GIMÉNEZ-PEREIRA, 2005). A significant number of enterococci can be found in the Feta (MANOLOPOULOU et al., 2003), Turkish white cheese, Caprino, Mozzarella, Venaco, Monte Veronese, Fontina, and Comté cheeses (GIRAFFA, 2003; ÖZMEN TOĞAY et al., 2016), as well as in French cheeses made from raw milk (JAMET et al., 2012).

So far, some enterococci have been used successfully in biopreservation, because they have the potential to inhibit the growth of food spoilage microorganisms. Enterococci produce lactic acid, which can reduce the $\mathrm{pH}$ and have an effect on cell membrane permeability. Also, enterococci can produce other antimicrobial substances, such as hydrogen peroxide, bacteriocin and bacteriocin-like inhibitory substances (ZHENG et al., 2015).

Lactic acid bacteria (LAB) isolated from cheese affect the ability of biofilm formation (GÓMEZ et al., 2016). It is well-known that the ability of biofilm formation is related to pathogenesis of bacterial strains. However, some recent studies (ELHADIDY and ZAHRAN, 2014; ŽIVKOVIĆ et al., 2016; POPOVIĆ et al., 2018) have indicated that the biofilm formation of LAB is more associated with adhesion properties, which have a role in gut colonization as well as in the probiotic potential of LAB.

The aims of this study were the isolation, identification and characterization of the physiological characteristics of the members of genus Enterococcus isolated from summer and autumn samples of traditionally made raw milk cheese from Sokobanja. Also, the aims were to screen their antimicrobial potential, as well as their ability for biofilm formation. Another aim was to compare these characteristics of the isolates with enterococci isolated from spring samples of cheese.

\section{Materials and methods}

The procedure of cheese-making, manufacture and sampling. The tested cheese was produced in countryside households around Sokobanja, (Southeastern Serbia), in the traditional way. The procedure of cheese-making, manufacture and sampling is described in detail in MLADENOVIĆ et al. (2018) and MURUZOVIĆ et al. (2018c). The samples were stored at $4{ }^{\circ} \mathrm{C}$ in a refrigerator until use. 
Isolation, identification and characterization of genus Enterococcus. The working sample $(10 \mathrm{~g})$ was taken with a sterile spoon from the middle of the cheese and mixed in a vortex with $90 \mathrm{~mL}$ of $2 \%$ sodium citrate solution ( $\mathrm{pH}$ 7.5) (Alkaloid, Skoplje, Macedonia), until complete homogenization was reached. Then, successive 10-fold dilutions (up to $10^{-7}$ ), with $2 \%$ sodium citrate, were prepared. $1 \mathrm{~mL}$ of each dilution was inoculated on bile esculin agar pH 7.1 (BEA, Torlak, Belgrade, Serbia) at $37^{\circ} \mathrm{C}$ for $72 \mathrm{~h}$, for presumptive enterococci (MANNU et al., 2002). Aerobic mesophilic bacteria (as an indicator of sanitary conditions during milking and milk handling) were enumerated on the nutrient agar (Torlak, Belgrade, Serbia). After solidification, bile esculin agar plates were covered with the same medium, in order to establish microaerophilic conditions. After incubation, the plates were selected for enumeration, and the number of bacteria was expressed as $\mathrm{CFU} / \mathrm{g}$ of the cheese.

The next approach was to pick single colonies randomly from the BEA agar plates and streak them on new agar plates for purification. A total of 90 isolates were subjected to microscopic observation, Gram staining and a catalase test. Further, 30 Gram-positive and catalase-negative isolates of LAB were identified to genus level by tests, as follows: growth at 15 and $45^{\circ} \mathrm{C}$ in $\mathrm{M} 17$ broth, growth at 4.0, 6.5 and 8.0\% (w/v) $\mathrm{NaCl}$ in $\mathrm{M} 17$ broth, production of carbon dioxide from glucose by subculturing the isolates in tubes with M17 broth and Durham's tubes, growth and production of slime from sucrose, L-arginine and esculin hydrolysis, hippurate hydrolysis, citrate utilization, diacetyl production, activity in milk with $0.1 \%$ methylene blue, and measured $\mathrm{pH}$ of pure milk and milk enriched with $2 \%$ glucose and $1 \%$ yeast extract, inoculated in overnight cultures.

Further, the isolated enterococci were identified using Microgen Strep ID (Microgen Bioproducts, Germany), according to the manufacturer's procedure. The isolated and identified strains were stored at $-80{ }^{\circ} \mathrm{C}$ in M17 broth containing $20 \%$ glycerol (v/v) (MANNU et al., 2002).

The use of MALDI-TOF mass spectrometry to identify enterococci. Isolates were grown overnight on M17 agar plates and analysed using the standard Bruker's direct transfer sample preparation procedure for MALDI-TOF MS. A single bacterial colony was spotted directly onto a 96-spot MALDI target plate (Bruker Daltonics, Bremen, Germany), allowed to dry, and immediately overlaid with $1 \mu \mathrm{L}$ of the matrix solution (Bruker Matrix HCCA; $\alpha$-Cyano-4-hydroxycinnamic acid).

MALDI-TOF mass spectra were obtained using Microflex LT/SH BioTyper spectrometer (Bruker Daltonics) equipped with a nitrogen laser $(337 \mathrm{~nm})$ under the control of Flexcontrol software ver. 3.1 (Bruker Daltonics). Spectra acquisition in a mass range of 2 to $20 \mathrm{kDa}$ were collected using the Auto Execute option, by accumulating 240 laser shots (laser frequency, $60 \mathrm{~Hz}$; ion source 1 voltage, $19.9 \mathrm{kV}$; ion source 2 voltage, 
$18.53 \mathrm{kV}$; lens voltage, $6 \mathrm{kV}$ ) acquired at $30-40 \%$ of maximum laser power. Score values $\geq 2.00$ were taken as correct identification to the species level (KRZYSZTOF et al., 2016).

Detection of antimicrobial potential. The agar-well diffusion method (TAGG and MC GIVEN 1971) was used for screening the antimicrobial potential of the isolated enterococci, using Escherichia coli ATCC 25922, Proteus mirabilis ATCC 12453, Klebsiella oxytoca KGPMF1, Klebsiella ornithinolytica KGPMF8, and Aeromonas hydrophila as indicator strains. The collection of isolates and ATCC stains were kept in a $20 \%$ glycerol $/$ medium mixture at $-80{ }^{\circ} \mathrm{C}$ at the Faculty of Science, University of Kragujevac. The indicator stains used in this test were isolated from cheese from Sokobanja (MLADENOVIĆ et al., 2018), in order to test and compare the influence of Enterococcus species on the growth inhibition of tested Gram-negative isolates in this cheese. The procedure was described in detail in MURUZOVIĆ et al., (2018a; 2018c).

Biofilm formation assay and quantification. The ability of isolated enterococci to form biofilms was tested as described by O'TOOLE et al. (2000), with some modifications as described below.

The tissue culture 96-well microtiter plates (Sarstedt, Germany) were prepared by dispensing $100 \mu \mathrm{L}$ of M17 broth in each well. $50 \mu \mathrm{L}$ of the initial bacterial suspension (containing about $10^{8} \mathrm{CFU} / \mathrm{mL}$ and diluted to $1: 100$ ) was added to each well. The inoculated plates were incubated at $37^{\circ} \mathrm{C}$ for $48 \mathrm{~h}$. After incubation, the content of each well was removed by tapping the plates. The wells were washed with $200 \mu \mathrm{L}$ of sterile $0.85 \%$ saline, in order to remove free-floating bacteria, and the biofilm was fixed with 100 $\mu \mathrm{L}$ of methanol. The biofilms were stained with crystal violet $(0.1 \% \mathrm{w} / \mathrm{v})$ and incubated at room temperature for 20 minutes. Excess stain was rinsed off by thorough washing with deionized water, and then with $200 \mathrm{~mL}$ of $96 \%$ ethanol. The optical densities (OD) of the bacterial biofilms were determined by an enzyme-linked immunosorbent assay (ELISA) plate reader (RT-2100C, Rayto, Shenzhen, China) at $630 \mathrm{~nm}$ wavelength.

Only M17 broth served as a control to check the sterility and non-specific binding of media. To compensate for background absorbance, OD readings from the dyed and fixated sterile medium were averaged and subtracted from the test values.

Statistical analysis. The ability of biofilm formation was presented as mean \pm SD and data were analysed using Microsoft Excel (Redmond, Washington, DC, USA). The Pearson coefficient of correlation between the counts of microbiological groups in the cheese samples and physicochemical parameters, as well as Spearman coefficient of correlation between time of incubation and $\mathrm{pH}$ in acidification process were calculated. The Paired - Samples T-test was used to compare the inhibitory effects of Enterococcus isolates and antibiotics the against indicator strains. These data were analysed using SPSS version 20 software (SPSS Inc., Chicago, IL, USA). 
M. Ž. Grujović et al.: Antimicrobial potential and ability of biofilm formation of autochthonous enterococci

\section{Results}

The total count of enterococci and aerobic mesophilic bacteria: The total count of viable aerobic mesophilic bacteria, enumerated on the nutrient agar, ranged between $1.6 \times 10^{7} \mathrm{CFU} / \mathrm{g}$ and $4.2 \times 10^{7} \mathrm{CFU} / \mathrm{g}$ of cheese in the summer, and between $4.3 \times 10^{7} \mathrm{CFU} / \mathrm{g}$ and $8.3 \times 10^{7} \mathrm{CFU} / \mathrm{g}$ of cheese in the autumn samples. The total count of viable enterococci, enumerated on the bile esculin agar (BEA) plates, ranged between $2 \times 10^{5} \mathrm{CFU} / \mathrm{g}$ and $1 \times 10^{6} \mathrm{CFU} / \mathrm{g}$ of cheese in the summer and between $3.1 \times 10^{5} \mathrm{CFU} / \mathrm{g}$ and $2.4 \times 10^{6} \mathrm{CFU} / \mathrm{g}$ of cheese in the autumn. The second sample did not contain enterococci, either in the summer or in the autumn (Table 1).

Table 1. Total number of bacteria in cheeses from Sokobanja

\begin{tabular}{|l|c|c|c|c|c|c|}
\hline \multirow{2}{*}{} & \multicolumn{3}{|c|}{ Summer } & \multicolumn{3}{c|}{ Autumn } \\
\cline { 2 - 7 } & Sample 1 & Sample 2 & Sample 3 & Sample 4 & Sample 5 & Sample 6 \\
\hline NA $^{\mathrm{a}}$ & $3.5 \times 10^{7 \mathrm{c}}$ & $1.6 \times 10^{7}$ & $4.2 \times 10^{7}$ & $4.3 \times 10^{7}$ & $8.3 \times 10^{7}$ & $5.4 \times 10^{7}$ \\
\hline BEA $^{\mathrm{b}}$ & $1 \times 10^{6}$ & n.d. & $2 \times 10^{5}$ & $2.4 \times 10^{6}$ & n.d. & $3.1 \times 10^{5}$ \\
\hline
\end{tabular}

${ }^{\mathrm{a}}$ - Nutrient agar; ${ }^{\mathrm{b}}$ - Bile esculin agar; ${ }^{\mathrm{c}}-\mathrm{CFU} / \mathrm{g}$ of cheese, average values of three independent experiments; n.d.- bacteria not detected; Sample 1, 2, 3 - summer sampling; Sample 4, 5, 6 - autumn sampling

Biochemical and physiological characteristics of enterococci. In this paper, the presence, biochemical and physiological characteristics of Enterococcus species isolated from Sokobanja cheese, were investigated. The results of biochemical and physiological abilities showed that 30 isolates belonged to the genus Enterococcus (Table 2). In the genera Enterococcus, four species were identified: E. faecium (8 isolates), E. faecalis (14 isolates), E. hirae (4 isolate) and E. durans (4 isolate).

Table 2. Biochemical and physiological characteristics of isolated enterococci

\begin{tabular}{|l|c|c|c|c|c|}
\hline \multirow{2}{*}{ Tests } & \multicolumn{4}{|c|}{ Enterococcus sp. } & \\
\cline { 2 - 6 } & E. faecium & E. faecalis & E. hirae & E. durans & $\begin{array}{c}\text { E. faecalis } \\
\text { ATCC 29211 }\end{array}$ \\
\hline Morphology & cocci & cocci & cocci & cocci & cocci \\
\hline Growth at $15^{\circ} \mathrm{C}$ & + & + & + & + & + \\
\hline Growth at $45^{\circ} \mathrm{C}$ & + & + & + & + & + \\
\hline Growth in $4 \% \mathrm{NaCl}$ & + & + & + & + & + \\
\hline Growth in $6.5 \% \mathrm{NaCl}$ & + & + & + & + & + \\
\hline Growth in $8 \% \mathrm{NaCl}$ & + & + & + & + & + \\
\hline Hydrolysis of arginine & + & + & + & - & + \\
\hline Hydrolysis of esculin & + & + & + & + & + \\
\hline
\end{tabular}

+ positive growth; - no growth 
M. Ž. Grujović et al.: Antimicrobial potential and ability of biofilm formation of autochthonous enterococci

Table 2. Biochemical and physiological characteristics of isolated enterococci (continued)

\begin{tabular}{|c|c|c|c|c|c|}
\hline \multirow[b]{2}{*}{ Tests } & \multicolumn{4}{|c|}{ Enterococcus sp. } & \multirow[b]{2}{*}{$\begin{array}{c}\text { E. faecalis } \\
\text { ATCC } 29211\end{array}$} \\
\hline & E. faecium & E. faecalis & E. hirae & E. durans & \\
\hline Hippurate hydrolysis & + & + & + & + & + \\
\hline Utilization of citrate & - & - & - & - & - \\
\hline Production of $\mathrm{CO}_{2}$ & - & - & - & - & - \\
\hline Production of diacetyl & - & - & - & - & - \\
\hline $\begin{array}{l}\text { Black zone on bile } \\
\text { esculin agar }\end{array}$ & + & + & + & + & + \\
\hline Production of slime & - & - & - & - & - \\
\hline $\begin{array}{l}\text { Growth in milk with } \\
0.1 \% \text { methylene blue }\end{array}$ & + & + & + & + & + \\
\hline
\end{tabular}

+ positive growth; - no growth

It was noticed that there were no significant differences in the number and diversity of enterococci between the summer and autumn samples. The exceptions were E. hirae isolates, which were only isolated in autumn samples (Table 3).

Table 3. The number of isolates of Enterococcus spp. isolated from cheese samples

\begin{tabular}{|l|c|c|c|c|c|c|}
\hline \multirow{2}{*}{ Species } & \multicolumn{3}{|c|}{ Summer sampling } & \multicolumn{3}{c|}{ Autumn sampling } \\
\cline { 2 - 7 } & Sample 1* & Sample 2 & Sample 3 & Sample 4 & Sample 5 & Sample 6 \\
\hline E. faecium & 1 & $/$ & 2 & 2 & $/$ & 3 \\
\hline E. faecalis & 3 & $/$ & 2 & 6 & $/$ & 3 \\
\hline E. hirae & $/$ & $/$ & $/$ & 1 & $/$ & 3 \\
\hline E. durans & 1 & $/$ & $/$ & 3 & $/$ & $/$ \\
\hline
\end{tabular}

* Number of isolates

All isolates show the ability for curd formation in pure and enriched milk, after $24 \mathrm{~h}$. Compared with pure milk as the control (at $0 \mathrm{~h}, \mathrm{pH}$ 6.3), all isolates showed acidification ability (pH about 6 at $6 \mathrm{~h}$ and 4.6 at $24 \mathrm{~h}$ ). In enriched milk (pH 6), the acidification ability was better (pH about 5.5 at $6 \mathrm{~h}$ and 4.2 at $24 \mathrm{~h}$ ). Only E. durans showed better acidification ability in pure milk (Fig. 1). The control pH measurement of the pure and enriched milk after $6 \mathrm{~h}$ and $24 \mathrm{~h}$ was restful (Fig. 1). 


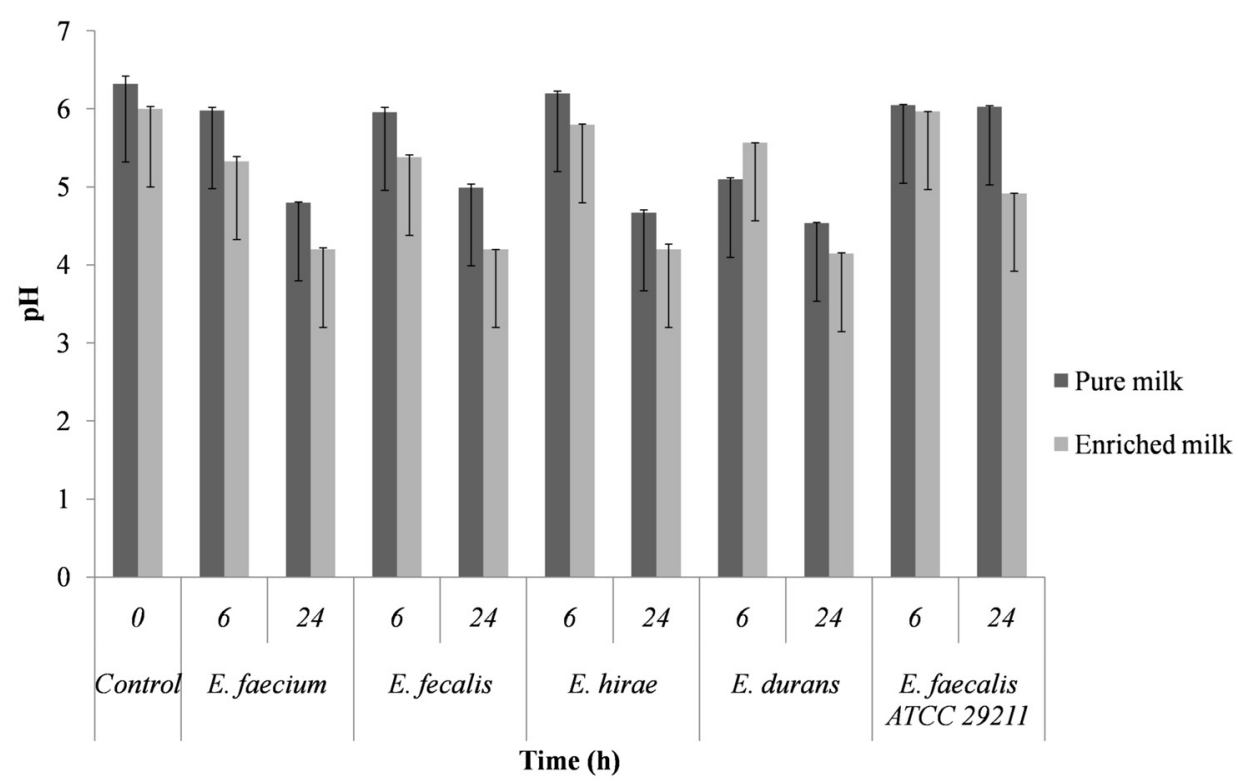

Fig. 1. Acidification ability of Enterococcus genera

Antimicrobial potential of isolated Enterococcus species. In this paper, the potential of isolated enterococci strains to inhibit the growth of indicator stains ( $E$. coli ATCC 25922, P. mirabilis ATCC12453, K. oxytoca KGPMF1, K. ornithinolytica KGPMF8, and $A$. hydrophila). The Enterococcus sp. which showed any inhibition zone diameters, are shown in Table 4. Assessment of the antagonistic potential of the isolated strains, compared to the effect of the selected antibiotics, was performed.

The inhibition zone diameters against E. coli ATCC 25922, were from 12 to 20 mm. The isolates KGPMF11, KGPMF12, KGPMF13, KGPMF15, and KGPMF20 did not inhibit E. coli ATCC 25922. Against P. mirabilis ATCC 12453, the inhibition zone diameters were from 10-22 mm. E. hirae KGPMF9 was not active against P. mirabilis ATCC 12453. K. oxytoca KGPMF1 showed no sensitivity to E. faecium KGPMF17, E. faecium KGPMF20, and E. faecalis KGPMF41, while for other Enterococcus isolates, the inhibition zones ranged from 12-20 mm. K. ornithinolytica KGPMF8 demonstrated no sensitivity to E. faecium KGPMF16, while the other tested isolates showed inhibition zones ranging from 10 to $16 \mathrm{~mm}$. All tested isolates inhibited the growth of $A$. hydrophila and the inhibition zones ranged from 10-14 $\mathrm{mm}$. 
M. Ž. Grujović et al.: Antimicrobial potential and ability of biofilm formation of autochthonous enterococci

Table 4. Antimicrobial activity of Enterococcus genera from cheeses from Sokobanja

\begin{tabular}{|c|c|c|c|c|c|c|c|c|c|c|}
\hline \multirow[b]{3}{*}{ Isolates } & \multicolumn{10}{|c|}{ Indicator stains } \\
\hline & \multicolumn{2}{|c|}{$\begin{array}{c}\text { E. coli ATCC } \\
25922\end{array}$} & \multicolumn{2}{|c|}{$\begin{array}{c}\text { P. mirabilis } \\
\text { ATCC } 12453\end{array}$} & \multicolumn{2}{|c|}{$\begin{array}{l}\text { K. oxytoca } \\
\text { KGPMF1 }\end{array}$} & \multicolumn{2}{|c|}{$\begin{array}{c}\text { K. ornithinolytica } \\
\text { KGPMF8 }\end{array}$} & \multicolumn{2}{|c|}{ A. hydrophila } \\
\hline & ZI* & $A^{*}$ & ZI & A & ZI & A & ZI & A & ZI & A \\
\hline $\begin{array}{l}\text { E. hirae } \\
\text { KGPMF9 }\end{array}$ & 15 & $\mathrm{C}$ & / & l & 17 & $\mathrm{C}$ & 10 & $\mathrm{C}$ & 14 & $\mathrm{C}$ \\
\hline $\begin{array}{l}\text { E. durans } \\
\text { KGPMF10 }\end{array}$ & 12 & $\mathrm{~T}$ & 13 & $\mathrm{C}$ & 11 & $\mathrm{~T}$ & 12 & $\mathrm{C}$ & 14 & $\mathrm{C}$ \\
\hline $\begin{array}{l}\text { E. faecium } \\
\text { KGPMF11 }\end{array}$ & l & l & 19 & $\mathrm{~T}$ & 12 & $\mathrm{C}$ & 12 & $\mathrm{C}$ & 12 & $\mathrm{C}$ \\
\hline $\begin{array}{l}\text { E. faecium } \\
\text { KGPMF12 }\end{array}$ & l & l & 14 & $\mathrm{C}$ & 15 & $\mathrm{C}$ & 12 & $\mathrm{C}$ & 12 & $\mathrm{C}$ \\
\hline $\begin{array}{l}\text { E. faecium } \\
\text { KGPMF13 }\end{array}$ & l & 1 & 18 & $\mathrm{~T}$ & 20 & $\mathrm{~T}$ & 14 & $\mathrm{C}$ & 12 & $\mathrm{C}$ \\
\hline $\begin{array}{l}\text { E. faecium } \\
\text { KGPMF14 }\end{array}$ & 20 & $\mathrm{~T}$ & 22 & $\mathrm{~T}$ & 14 & $\mathrm{C}$ & 12 & $\mathrm{C}$ & 12 & $\mathrm{C}$ \\
\hline $\begin{array}{l}\text { E. faecium } \\
\text { KGPMF15 }\end{array}$ & l & l & 22 & $\mathrm{~T}$ & 12 & $\mathrm{C}$ & 12 & $\mathrm{C}$ & 12 & $\mathrm{C}$ \\
\hline $\begin{array}{l}\text { E. faecium } \\
\text { KGPMF16 }\end{array}$ & 17 & $\mathrm{~T}$ & 19 & $\mathrm{~T}$ & 12 & $\mathrm{C}$ & I & l & 12 & $\mathrm{C}$ \\
\hline $\begin{array}{l}\text { E. faecium } \\
\text { KGPMF17 }\end{array}$ & 20 & $\mathrm{~T}$ & 17 & $\mathrm{~T}$ & l & 1 & 12 & $\mathrm{C}$ & 12 & $\mathrm{C}$ \\
\hline $\begin{array}{l}\text { E. faecium } \\
\text { KGPMF18 }\end{array}$ & 16 & $\mathrm{C}$ & 15 & $\mathrm{~T}$ & 12 & $\mathrm{C}$ & 16 & $\mathrm{C}$ & 14 & $\mathrm{C}$ \\
\hline $\begin{array}{l}\text { E. faecium } \\
\text { KGPMF19 }\end{array}$ & 12 & $\mathrm{C}$ & 16 & $\mathrm{C}$ & 14 & $\mathrm{C}$ & 12 & $\mathrm{C}$ & 12 & $\mathrm{C}$ \\
\hline $\begin{array}{l}\text { E. faecium } \\
\text { KGPMF20 }\end{array}$ & 1 & 1 & 20 & $\mathrm{~T}$ & 1 & I & 10 & $\mathrm{C}$ & 12 & $\mathrm{C}$ \\
\hline $\begin{array}{l}\text { E. faecalis } \\
\text { KGPMF41 }\end{array}$ & 16 & $\mathrm{C}$ & 17 & $\mathrm{~T}$ & I & 1 & 16 & $\mathrm{C}$ & 10 & $\mathrm{C}$ \\
\hline $\begin{array}{l}\text { E. faecalis } \\
\text { KGPMF42 }\end{array}$ & 17 & $\mathrm{~T}$ & 10 & $\mathrm{C}$ & 12 & $\mathrm{C}$ & 10 & $\mathrm{C}$ & 12 & $\mathrm{C}$ \\
\hline $\begin{array}{l}\text { E. faecalis } \\
\text { ATCC } 29211\end{array}$ & 1 & I & I & I & 1 & 1 & 1 & 1 & 1 & I \\
\hline
\end{tabular}

$\mathrm{ZI}^{*}$ - zone of growth inhibition given in mm (millimeter); $\mathrm{A}^{*}$ - zone appearance (C - clear zone of inhibition; $\mathrm{T}$ - turbid zone of inhibition; / - no zone of inhibition) 
Ability of biofilm formation. The ability of enterococci isolates to form a biofilm was evaluated using the crystal violet method. E. hirae KGPMF9 and E. faecium KGPMF14 showed the ability for biofilm formation, with absorbance values of $0.03 \pm 0.02$ and 0.04 \pm 0.02 , respectively. The rest of the isolates showed no ability for biofilm formation.

\section{Discussion}

In this paper, the presence, biochemical and physiological characteristics of Enterococcus genera, isolated from summer and autumn samples of cheeses from Southeastern Serbia (Sokobanja), were investigated. Previously, the community of LAB from Sokobanja cheese spring samples was described in MURUZOVIĆ et al. (2018a). Also, the community of genus Streptococcus from summer and autumn samples of cheese was presented in MURUZOVIĆ et al. (2018c). The community of enterococci from summer and autumn samples is described in this paper for the first time, in order to compare the community of $\mathrm{LAB}$, with particular emphasis on enterococci, at different times of the year.

The numbers of enterococci vary with the cheese type, the starter used, and the production season. The different levels of enterococci in different cheeses may be influenced by the ability of bacteria to survive in the dairy environment, as well as the ability of surviving and growth ability under different conditions of cheese manufacture and ripening (GIRAFFA, 2003; GIMÉNEZ-PEREIRA, 2005). Levels of enterococci may range from $10^{4}$ to $10^{6} \mathrm{CFU} / \mathrm{g}$ in cheese curds, whereas in fully ripened cheeses, levels may vary from $10^{5}$ to $10^{7} \mathrm{CFU} / \mathrm{g}$ (FRANZ et al. 2003), which was confirmed in our research. In spring samples of Sokobanja cheese, the number of enterococci ranged between $2 \times 10^{5}$ and $4 \times 10^{5} \mathrm{CFU} / \mathrm{g}$ of cheese (MURUZOVIĆ et al., 2018a), which was a lower number than in the summer and autumn samples. Streptococcus isolates were only obtained from summer samples of cheese. A higher number of enterococci were found in the first sample from summer and autumn. The reason may be found in the nutrition of the cows. According to the results described in MURUZOVIĆ et al. (2018b), the correlation was calculated between the chemical composition of the cheese and the number of enterococci. The negative coefficients of correlation between the content of $\mathrm{NaCl}, \mathrm{S} / \mathrm{M}$ and enterococci $(\mathrm{r}=-1$ and $\mathrm{r}=-1, \mathrm{P}<0.01)$ suggest the inhibitory effect of high salt content and salt in moisture. The positive coefficient of correlation between $\mathrm{pH}$ and enterococci $(\mathrm{r}=1, \mathrm{P}<0.01)$ is expected, because it is known that they can cause lower $\mathrm{pH}$ values in three day old cheese.

The high number of aerobic mesophilic bacteria in cheese may be the result of the season and the ambient temperature during ripening (BONETTA et al., 2008). According to LEVKOV et al. (2014), the number of aerobic mesophilic bacteria tends to increase after curdling, which is a result of their multiplication and physical entrapment, and they 
reach their maximum values on the second day of ripening $\left(5.22 \times 10^{6}-1.25 \times 10^{7} \mathrm{CFU} / \mathrm{g}\right.$ of cheese), which is in accordance with our research. In spring samples of Sokobanja cheese MURUZOVIĆ et al. (2018a) showed that the number of aerobic mesophilic bacteria ranged between $1.8 \times 10^{7}$ and $1.2 \times 10^{8} \mathrm{CFU} / \mathrm{g}$ of cheese, which was a higher number than in the summer and autumn samples. The negative coefficients of correlation between the content of $\mathrm{NaCl}, \mathrm{S} / \mathrm{M}$ and aerobic mesophilic counts $(\mathrm{r}=-0.94$ and $\mathrm{r}=-0.37, \mathrm{P}<0.05)$ suggest the inhibitory effect of high salt content and salt in moisture. The negative coefficient of the correlation between the $\mathrm{pH}$ and the aerobic mesophilic bacteria $(\mathrm{r}=$ $-0.97, \mathrm{P}<0.01)$ might indicate the possible adaptation of microorganisms to the lower $\mathrm{pH}$ values in the cheese.

MORMILE et al. (2016) indicated that E. faecium proved to be the dominant species in "Pecorino di Tramonti" cheese, followed by E. faecalis and E. durans. GIRAFFA(2003) and MRKONJIĆ FUKA et al. (2017) noticed that E. faecium, E. faecalis, and E. hirae are the most frequent and prevalent enterococci species isolated from cheeses, which was confirmed in our paper, too. Only E. faecium and E. faecalis species were found in spring samples of Sokobanja cheese (MURUZOVIĆ et al., 2018a). However, no differences between their biochemical characteristics were noticed. The isolates showed significantly better acidification ability in enriched milk $(\mathrm{P}<0.05)$. A negative linear correlation was shown for the time of incubation and $\mathrm{pH}$ in pure and enriched milk $(\mathrm{r}=-0.91$ and -0.93 , respectively). Both correlations were significant $(\mathrm{P}<0.05)$. When comparing the results of acidification ability, it may be concluded that all isolates showed significantly better acidification ability than E. faecalis ATCC 2921. Enterococci from spring samples of cheese also showed good acidification ability (MURUZOVIĆ et al., 2018a).

A natural cheese isolate, E. faecium RZS C5, may produce bacteriocin, which showed strong activity on the growth of $L$. monocytogenes. Enterococci are interesting additives for foods. Their inhibitory activity encompasses food spoilers and food borne pathogens, so they could contribute to the prevention of food contamination as natural food preservatives (GIMÉNEZ-PEREIRA, 2005; LEROY et al., 2003; HASSANZADAZAR et al., 2014). Also, ÖZMEN TOĞAY et al. (2016) indicated that Enterococcus spp. isolated from traditional Turkish cheeses have an antagonistic effect against $L$. monocytogenes, $L$. innocua, L. ivanovii, and S. aureus. In our study, Enterococcus isolates showed moderate inhibitory activity on the tested indicator stains. Enterococci isolated from spring samples showed inhibition zone diameters from 10-14 mm (MURUZOVIĆ et al., 2018a), which was similar to the results in this study. Inhibition zones against E. coli ATCC 25922 and P. mirabilis ATCC 12453 were higher, but the inhibition of isolates from the same cheese was similar. It may be concluded that the inhibition zones were stain specific.

According to the results of antibiotic sensitivity described in MLADENOVIĆ et al. (2018) and MURUZOVIĆ et al. (2018c), chloramphenicol showed a better effect on 
indicator stains than all the tested enterococci $(\mathrm{P}<0.05)$. Streptomycin showed a better effect than E. durans KGPMF10 and E. faecalis KGPMF19, on all indicator stains $(\mathrm{P}<0.05)$. Other tested pairs did not show any significant difference $(\mathrm{P}>0.05)$. Based on these results, it could be concluded that Enterococcus isolates showed moderate inhibitory activity, compared to the tested antibiotics.

GOMES et al. (2008) indicated that some foodborne E. faecalis and E. faecium isolates had the ability to form weak, moderate or strong biofilms, while some isolates formed no biofilm at all. NECIDOVA et al. (2009) investigated the ability of biofilm formation of E. faecalis and E. faecium isolated from milk, and some final products (cheese and curd cheese). They showed that E. fecium formed a biofilm in a higher number of stains than E. fecalis. This result was found in our study too. NECIDOVA et al. (2009) also indicated that Enterococcus isolates from cheese and curd cheese showed no ability of biofilm formation, while isolates from bulk tank milk samples mainly formed a biofilm. It has been found that $E$. durans had the ability to form a strong or moderate biofilm (AMEL et al., 2015), but in our work it showed no ability to form a biofilm. $E$. hirae was a weak biofilm producer according to DIAZ et al. (2016), which was confirmed in our study, too. In our research, only two isolates of Enterococcus sp. had the ability for biofilm formation.

\section{Conclusion}

The results of this study contribute to better knowledge of the presence of indigenous microflora in traditionally made cheese from Sokobanja. According to the results, it may be concluded that the tested enterococci showed antagonistic potential on the growth of enterobacteria isolated from the same cheese. Further investigations need to include molecular research of the isolated enterococci and detection of the antimicrobial compounds that they produce. It is also necessary to evaluate the safety aspects of the tested enterococci and their potential application as probiotics.

\section{Conflicts of interest}

The author(s) declare no potential conflicts of interest with respect to the research, authorship, and/or publication of this article.

\section{Acknowledgements}

The investigation was supported by the Ministry of Education, Science and Technological Development of the Republic of Serbia [41010]. 
M. Ž. Grujović et al.: Antimicrobial potential and ability of biofilm formation of autochthonous enterococci

\section{References}

AMEL, A. M., B. FARIDA, S, DJAMILA (2015): Anti-adherence potential of Enterococcus durans cells and its cell-free supernatant on plastic and stainless steel against foodborne pathogens. Folia Microbiol. (Praha) 60, 357-363.

DOI: $10.1007 / \mathrm{s} 12223-014-0367-6$

BONETTA, S., J. D. COÏSON, D. BARILE, F. TRAVAGLiA, G. PIANA, E. CARRARO, M. ARLORIO (2008): Microbiological and chemical characterization of a typical Italian cheese: Ribola di Roccaverano. J. Agric. Food Chem. 56, 7223-7230.

DOI: $10.1021 /$ jf8000586

DIAZ, M., V. LADERO, B. DEL RIO, B. REDRUELLO, M. FERNÁNDEZ, M. C. MARTIN, M. A. ALVAREZ (2016): Biofilm-forming capacity in biogenic amine-producing bacteria isolated from dairy products. Front. Microbiol. 7, 1-10.

DOI: $10.3389 /$ fmicb.2016.00591

ELHADIDY, M., E. ZAHRAN (2014): Biofilm mediates Enterococcus faecalis adhesion, invasion and survival into bovine mammary epithelial cells. Lett. Appl. Microbiol. 58, 248-254. DOI: $10.1111 /$ lam.12184

FRANZ, C., M. E. STILES, K. H. SCHLEIFER, W. H. HOLZAPFEL (2003): Enterococci in foods-a conundrum for food safety. Int. J. Food Microbiol. 88, 105-122.

GIMÉNEZ-PEREIRA, M. L. (2005): Enterococci in milk products. Master Degree, Massey University Palmerston North, New Zealand.

GIRAFFA, G. (2003): Functionality of enterococci in dairy products. Int. J. Food Microbiol. 88, 215-222.

DOI: $10.1016 / \mathrm{s} 0168-1605(03) 00183-1$

GOMES, B. C., C. T. ESTEVES, I. C. PALAZZO, A. L. DARINI, G. E. FELIS, L. A. SECHI, B. D. G. M. FRANCI, E. C. P. DE MARTINIS (2008): Prevalence and characterization of Enterococcus spp. isolated from Brazilian foods. Food Microbiol. 25, 668-675.

DOI: $10.1016 /$ j.fm.2008.03.008

GÓMEZ, N. C., J. M. P. RAMIRO, B. X. V. QUECAN, B. D. G. DE MELO FRANCO (2016): Use of potential probiotic lactic acid bacteria (LAB) biofilms for the control of Listeria monocytogenes, Salmonella typhimurium, and Escherichia coli O157:H7 biofilms formation. Front. Microbiol. 7, 863.

DOI: $10.3389 /$ fmicb.2016.00863

HASSANZADAZAR, H., A. EHSANI, K. MARDANI (2014): Antibacterial activity of Enterococcus faecium derived from Koopeh cheese against Listeria monocytogenes in probiotic ultra-filtrated cheese. Vet. Res. Forum 5, 169-175.

JAMET, E., E. AKARY, M. A. POISSON, J. F. CHAMBA, X. BERTRAND, P. SERROR (2012): Prevalence and characterization of antibiotic resistant Enterococcus faecalis in French cheeses. Food Microbiol. 31, 191-198.

DOI: 10.1016/j.fm.2012.03.009 
M. Ž. Grujović et al.: Antimicrobial potential and ability of biofilm formation of autochthonous enterococci

KRZYSZTOF, F., T. DANILUK, A. FIODOR, E. DREWICKA, K. BUCZYNSK, K. LESZCZYNSKA, D. K. BIDESHI, I. SWIECICKA (2016): MALDI-TOF MS portrait of emetic and non-emetic Bacillus cereus group members. Electrophoresis 37, 2235-2247.

LEROY, F., M. R. FOULQUIE MORENO, L. DE VUYST (2003): Enterococcus faecium RZS C5, an interesting bacteriocin producer to be used as a co-culture in food fermentation. Int. J. Food Microbiol. 88, 235-240.

DOI: $10.1016 / \mathrm{s} 0168-1605(03) 00185-5$

LEVKOV, V., S. SRBINOVSKA, N. GJORGOVSKA (2014): Microbiological and chemical characteristics of traditional ewe's milk cheese from Mariovo region. Mljekarstvo 64, 195-206.

DOI: $10.15567 / \mathrm{mljekarstvo.2014.0307}$

MANNU, L., G. RIU, R. COMUNIAN, M. C. FROZZI, M. F. SCINTU (2002): A preliminary study of lactic acid bacteria in whey starter culture and industrial Pecorino Sardo ewes, milk cheese: PCR-identification and evolution during ripening. Int. Dairy J. 12, 17-26.

DOI: $10.1016 / \mathrm{s} 0958-6946(01) 00163-7$

MANOLOPOULOU, E., P. SARANTINOPOULOS, E. ZOIDOU, A. AKTYPIS, E. MOSCHOPOULOU, I. G. KANDARAKIS, E. M. ANIFANTAKIS (2003) Evolution of microbial populations during traditional Feta cheese manufacture and ripening. Int. J. Food Microbiol. 82, 153-161.

DOI: $10.1016 / \mathrm{s} 0168-1605(02) 00258-1$

MLADENOVIĆ, K. G., M. Ž. MURUZOVIĆ, T. D. ŽUGIĆ PETROVIĆ, O. D. STEFANOVIĆ, L. R. ČOMIĆ (2018): Isolation and identification of Enterobacteriaceae from traditional Serbian cheese and their physiological characteristics. J. Food Saf. 38, 1-9.

DOI: $10.1111 /$ jfs. 12387

MORMILE, A., M. BARILE, R. MERCOGLIANO, P. JOHANSSON, K. J. BJÖRKROTH, M. APONTE, N. MURRU (2016): Dynamics of lactic acid bacteria in "Pecorino di Tramonti" a ewe's milk cheese with particular emphasis on enterococci: a preliminary study. Ann. Microbiol. 66, 179.

DOI: $10.1007 / \mathrm{s} 13213-015-1094-1$

MOTAHARI, P., S. MIRDAMADI, M. KIANIRAD (2017): Safety evaluation and antimicrobial properties of Lactobacillus pentosus $22 \mathrm{C}$ isolated from traditional yogurt. J. Food Measure. Character. 11, 972-978.

DOI: $10.1007 / \mathrm{s} 11694-017-9471-\mathrm{Z}$

MRKONJIĆ FUKA, M., A. ZGOMBA MAKSIMOVIĆ, I. TANUWIDJAJA, N. HULAK, M. SCHLOTER (2017): Characterization of Enterococcal community isolated from an Artisan Istrian raw milk cheese: biotechnological and safety aspects. Food Technol. Biotechnol. 55, 368-380.

DOI: $10.17113 / \mathrm{ftb} .55 .03 .17 .5118$

Vet. arhiv 89 (5), 653-667, 2019 
M. Ž. Grujović et al.: Antimicrobial potential and ability of biofilm formation of autochthonous enterococci

MURUZOVIĆ, M. Ž., K. G. MLADENOVIĆ, T. D. ŽUGIĆ PETROVIĆ, ČOMIĆ L. R. (2018c): In vitro evaluation of the antimicrobial potential of Streptococcus uberis isolated from a local cheese from Southeastern Serbia. Vet. arhiv 88, 521-534.

DOI: $10.24099 /$ vet.arhiv.0007

MURUZOVić, M. Ž., K. G. MLADENOVIĆ, M. D. DJILAS, O. D. STEFANOViĆ, L. R. ČOMIĆ (2018b): In vitro evaluation of antimicrobial potential and ability of biofilm formation of autochthonous Lactobacillus spp. and Lactococcus spp. isolated from traditionally made cheese from Southeastern Serbia. J. Food Process. Pres.

DOI:10.1111/jfpp.13776

MURUZOVIĆ, M. Ž., K. G. MLADENOVIĆ, T. D. ŽUGIĆ PETROVIĆ, L. R. ČOMIĆ (2018a): Characterization of lactic acid bacteria isolated from traditionally made Serbian cheese and evaluation of their antagonistic potential against Enterobacteriaceae. J. Food Process. Pres.

DOI:10.1111/jfpp.13577

NECIDOVÁ, L., B. JANŠTOVÁ, S. KARPÍŠKOVÁ, Š. CUPÁKOVÁ, M. DUŠKOVÁ, R. KARPÍŠKKOVÁ (2009): Importance of Enterococcus spp. for forming a biofilm. Czech J. Food Sci. 27, 354-356.

DOI: $10.17221 / 1087$-cjfs

O'TOOLE, G., H. B. KAPLAN, R. KOLTER (2000): Biofilm formation as microbial development. Ann. Rev. Microbiol. 54, 49-79.

DOI: 10.1146/annurev.micro.54.1.49

ÖZMEN TOĞAY, S., M. AY, S. SANDIKÇI ALTUNATMAZ, F. YILMAZ AKSU, Ö. EROL TINAZTEPE, G. İSSA, S. K. BÜYÜKÜNAL (2016): Antimicrobial activity potential of Enterococcus spp. isolated from some traditional Turkish cheeses. Kafkas. Univ. Vet. Fak. Derg. 22, 765-770.

DOI: $10.9775 / \mathrm{kvfd} .2016 .15369$

POPOVIĆ, N., M. DINIĆ, M. TOLINAČKI, S. MIHAJLOVIĆ, A. TERZIĆ-VIDOJEVIĆ, S. BOJIĆ, J. DJOKIĆ, N. GOLIĆ, K. VELJOVIĆ (2018): New insight into biofilm formation ability, the presence of virulence genes and probiotic potential of Enterococcus sp. dairy isolates. Front. Microbiol. 9, 78.

DOI: $10.3389 /$ fmicb.2018.00078

TAGG, J. R., A. R. MC GIVEN (1971): Assay system for bacteriocins. Appl. Microbiol. 21, 943.

TERZIĆ-VIDOJEVIĆ, A., K. VELJOVIĆ, M. TOLINAČKI, M. NIKOLIĆ, M. OSTOJIĆ, L. TOPISIROVIĆ (2009): Characterization of lactic acid bacteria isolated from artisanal Zlatar cheeses produced at two different geographical location. Genetika 41, 117-136.

DOI: $10.2298 /$ gensr0901117t

ZHENG, W., Y. ZHANG, L. HUI-MIN, L. DAN-TING, Z. L. ZHANG, Z. X. TANG, L. E. SHI (2015): Antimicrobial activity and safety evaluation of Enterococcus faecium KQ 2.6 isolated from peacock feces. BMC Biotechnol. 15, 1-30.

DOI: $10.1186 / \mathrm{s} 12896-015-0151-\mathrm{y}$ 
M. Ž. Grujović et al.: Antimicrobial potential and ability of biofilm formation of autochthonous enterococci

ŽIVKOVIĆ, M., M. S. MILJKOVIĆ, P. RUAS-MADIEDO, M. B. MARKELIĆ, K. VELJOVIĆ, M. TOLINAČKI, S. SOKOCIĆ, A. KORAĆ, N. GOLIĆ (2016): EPS-SJ exopolisaccharide produced by the strain Lactobacillus paracasei subsp. paracasei BGSJ2-8 is involved in adhesion to epithelial intestinal cells and decrease on E. coli association to Caco-2 cells. Front. Microbiol. 7, 286.

DOI: $10.3389 /$ fmicb.2016.00286

\section{GRUJOVIĆ, M. Ž., K. G. MLADENOVIĆ, T. D. ŽUGIĆ-PETROVIĆ, LJ. R. ČOMIĆ: Antagonistički potencijal i sposobnost stvaranja biofilma bakterija Enterococcus spp. izoliranih iz sira u Srbiji. Vet. arhiv 89, 653-667, 2019. \\ SAŽETAK}

U ovom je radu istražena prisutnost te biokemijske i fiziološke značajke bakterija iz roda Enterococcus, izoliranih iz domaćeg sira u Srbiji, proizvedenoga na tradicionalan način. Biokemijskim testom i masenom spektrometrijom MALDI-TOF dokazani su Enterococcus faecium (8 izolata), E. faecalis (14 izolata), E. hirae (4 izolata) i $E$. durans (4 izolata). Svi su analizirani izolati pokazali dobru sposobnost acidifikacije u sirovu i obogaćenom mlijeku. Istraženi su antagonizam enterokoka na rast bakterija Escherichia coli ATCC 25922, Proteus mirabilis ATCC 12453, Klebsiella oxytoca KGPMF1, Klebsiella ornithinolytica KGPMF8 i Aeromonas hydrophila te njihova sposobnost stvaranja biofilma. Analizirani izolati pokazali su umjerenu inhibicijsku aktivnost $(10-22 \mathrm{~mm}) \mathrm{u}$ rastu navedenih sojeva. Među izolatima samo su E. hirae KGPMF9 i E. faecium KGPMF14 pokazali sposobnost stvaranja biofilma. Rezultati ove studije daju temelj za daljnja istraživanja mogućnosti praktične primjene izoliranih enterokoka.

Ključne riječi: antimikrobni potencijal; biofilm; Enterococcus faecium; Enterococcus faecalis; Enterococcus durans; tradicionalno proizveden sir 
